\title{
Michael Richardson
}

\section{Who Speaks? Torture and the Ethics of Voice}

\begin{abstract}
This paper performs, in three movements, an exploration of the ethics not of torture itself but of writing it creatively. First movement: of the right to write. This first movement considers ethical questions of authorship in the fictional narration of the trauma of torture. It employs Giorgio Agamben's work on biopower and testimony to position the act of writing creatively about torture in relation to torture's political project and the subjection of the body to sovereign power, along with a reading of torture as affective encounter, to suggest the necessity of writing literary testimony to it. Second movement: of writing the torturer's voice. The second movement draws on Deleuzian affect theory to articulate a relational conception of this trauma that suggests, however distasteful, the need for the torturer's voice to be heard beyond the torture chamber. Third movement: of being affected by unjust ethics. This third movement draws on concepts of affective contagion to gestures back towards the experience of being affected by writing unjust ethics. With their twists and turns, their connections and discontinuities, these movements navigatenecessarily incompletely - the messy complexities of the ethical space of voice in the writing torture.

Keywords: Torture, affect, contagion, ethics, voice, biopower, testimony
\end{abstract}

When I tell people that I am writing a novel about torture their reaction is often the same. Raised eyebrows, a pause before a retreating, noncommittal response. I struggle to explain myself. Words like fascinated and attracted stick in my throat, and those without moral complication tumble forth: outraged, disgusted, necessary. There is a visceral difficulty, a bodily complexity of answering that marks the fraught ethical space of voicing torture.

Torture always involves voice. There is the voice of the victim crying out - in pain or to confess, to inform, to construct - even as its pain, whether mental or physical, seeks to reduce the voice to a wordless and world-destroying scream. This is what Elaine Scarry (1985) contends - that even as torture demands speech its pain erases the very possibility of speaking. This simultaneous destruction of language and exhortation to speech is part of what makes torture such a radical and total assault. Yet even in those extreme instances of pain there is always the voice of the torture, the voice that demands answer, that questions.

But torture is concerned not with the voice alone: there is, too, the body from which it issues. This is equally true of both 'psychological' and 'physical' tortures. Indeed, as Darius Rejali suggests, it is debatable whether a distinction between these two forms is even meaningful (Rejali 2007: 381). Physical abuse incurs deep psychological, as well as physical trauma, while 'psychological' techniques such as sleep deprivation result in weight loss, shaking and even 
organ failure. It is perhaps more useful to think of the tortured body as encompassing the whole of person: the physical and psychological, as well as the cultural, political and even spiritual. As I will show here, such an understanding of the body is necessary to develop a relational conception of tortured, torturing and writing bodies. The tortures of the war on terror whether the more physical, such as stress positions and waterboarding, or the more psychological, such as sleep deprivation or barrages of strobe lighting and heavy metal music - are no exception to this obsession with voice: each seeks to subjugate the body so that from it may be drawn a subjected voice, one that affirms America's war on terror. To write fictively of torture, as I currently am in my creative practice, is to engage this question of voice and the tortured and torturing bodies from which it speaks.

The Latin root of the word is torquere, 'to twist'; an oddly beautiful and yet violently forceful word. It carries within it both elegant movement and the grinding of joints; to twist the body and through it the voice. Torture, then, is concerned not only with speaking, but with movement, with relations of force and constraint. My focus in this paper is not the ethics of the act itself - many have written both excellent and deplorable works on that subject. Taking my cue from the word's etymology, I intend to navigate in three movements (necessarily incompletely) the ethics of writing torture in fiction.

\section{First movement: of the right to write}

I have never been tortured. Nor have I tortured another. Yet I write - and write creatively - of these things. The possibility that this distance is unbridgeable presses upon me. I want to slip away, escape into writing something else. But I can't. I am compelled. Why? The desire for justice, a naïve belief in the power of literature, a fascination with dark places - does it matter? This question simply hides another: by what right do I write?

Truthful testimony, the testimony of the eyewitness, is vital. But those which do emerge from Guantanamo Bay, Bagram Air Base and elsewhere - such as recent memoirs by David Hicks (2010), Murat Kurnaz (2008) or Moazzam Begg (2008) - are questioned (by authorities, by society) on their factual veracity rather than read for the truth of the experience they recount. There is room here for the literary, for creativity, to work. Perhaps there is, indeed, a necessity for the testimony of experience to be met and complemented by the testimony of literature, as works by Albert Camus, Arthur Koestler, George Orwell, Eli Wiesel and Primo Levi, among others, have done for some of the great political tragedies of modern times.

Not every witness to terrible events is an eyewitness. Primo Levi's witnessing of the camps of Nazi Germany does not preclude Albert Camus, in novels such as The Plague or The Fall, from bearing witness to the tragedies of the Holocaust. Felman and Laub suggest that literature has the potential to bridge the collapse of meaning that results from catastrophic trauma.

The specific task of the literary testimony is ... to open up in that belated witness, which the reader now historically becomes, the imaginative capability of perceiving history what is happening to others - in one's own body, with the power of sight (of insight) usually afforded only by one's own immediate physical involvement. (Felman \& Laub 1992: 108)

This 'imaginative capability of perceiving history' is precisely not what eyewitness testimony, in the juridical sense, provides. The woman at the 
window who saw a murder gives one perspective, the crime author who takes that murder and crafts a narrative around it offers another. If the value of the eyewitness resides in the correspondence of their testimony to evidence, then what matters in literary testimony is what the text does. The ethical practice of literary testimony, then, might be said to reside in its affect rather than any right per se. I, the writer, take on the task of translation, the 'deciphering of signs' that 'make[s] history available to the imaginative act' $(1992: 93,108)$. The question of the right to write cannot be extricated from what is written - and what it is that writing does. Writing torture demands an imaginative exposure of not only its trauma, but the nature of the very power that makes such radical violation of the body possible.

Modern state power is what Foucault called biopower, which for Agamben describes 'the concrete ways in which power penetrates subjects' very bodies and forms of life' (Agamben 1998: 5). This is power that seeks to bring all of life within its ambit, whether via human rights codes, the genetic databases of law enforcement agencies, or euthanasia laws. If your fingerprints have been scanned on entry into the United States since 9/11 you have brushed up close to biopower in its national security cloaking. Good intentions are not relevant here - it is the inclusion of more and more dimensions of living into the domain of power which both Foucault and Agamben wish to highlight. Torture, in its contemporary American incarnation in the war on terror, embodies this biopolitical trajectory of the modern state. Under the United States' post-9/11 laws both the tortured and the torturer operate within a 'state of exception... in which law encompasses living beings by means of its own suspension' (Agamben 2005: 3). Think of those detained at Guantanamo, for example, a site chosen precisely for its supposed positioning outside US domestic law yet within the full force of the state's military power. In contrast to the great and terrible example of modern biopower, Nazi Germany, this American incarnation is not concerned with death - crucially, the survival of tortured detainees allows the state to claim that American ideals remain intact. The victim lives but their voice is erased and spoken over by the state: the assertion of just cause, of potential threats, of securing us all. Revelations of abuse by released detainees such as Hicks or Begg are overwhelmed by unassailable claims of necessity by the American state. Indeed, as Agamben writes, 'The decisive activity of biopower in time consists in the production not of life or death, but rather of a mutable and virtually infinite survival' (Agamben 2002: 155). Detainees at Guantanamo, Bagram and elsewhere survive precisely to ensure the continued vitality of America's sovereign power.

How, then, to speak of both the event itself, the act of torture, and of its survival? Felman and Laub suggest that literary testimony has the capacity to 'speak beyond words' (Felman and Laub 1992: 278). That is to say, literary writing can somehow bridge the impossible gap of experience between victim, perpetrator and bystander. Here, Agamben diverges from Felman and Laub. By not directly addressing this gap, he argues, by declaring it incommensurable, they 'aestheticize testimony' (Agamben 2002: 36). 'Testimony,' writes Agamben, 'is a potentiality that becomes actual through an impotentiality of speech; it is, moreover, an impossibility that gives itself existence through a possibility of speaking' (2002: 146). Testimony is the voice of the subject spoken from within the intimate indistinction of being both able to speak and not. And thus, writes Agamben, 'with its every word, testimony refutes precisely this isolation of survival from life' (2002: 157). Literary testimony, then, is crucial to the great stuggle of modern life: resistance to state power.

So far, this movement has been a turning outward - I want now to continue further, to twist inward. A necessarily dangerous movement, since it risks both exposure and entrapment. Theorizing literary testimony in this way has 
couched the right to write as being bound up with both the need and capacity to do so. All very well, but how can my writing do justice to its subject?

Perhaps what resides here is shame: the shame of faking it, of exposing my writing as inadequate, of a profound and unbridgeable lack of authenticity (whatever such a thing might be). This shame holds me back, stays my hands on the keyboard, impels me to avoid the subject of my writing in conversation. But, as Elspeth Probyn suggests, 'writing shame is a visceral reminder to be true to interest, to be honest why or how certain things are of interest' (Probyn 2010: 73). I feel it, bodily, in my continual encountering of torture through text. The very otherness of torture implicates me. 'Shame,' writes Probyn, 'is an affect that crosses many different orders of bodies' (2010: 82). Is this, perhaps, what can connect my writing to my subject?

Bodies in the act of torture, both tortured and torturing, encounter one another flesh upon flesh but also in the violent collision of affect. By affect, I refer to the 'ways in which the body can connect with itself and the world' and its 'capacities for acting and being acted upon' (Massumi 1992: 93, 36). But - and not without caution - I am also using the term in Tomkins' (1963) sense, as those specific, pre-cognitive and visceral experiences that shape and change bodies. Disgust, fear, contempt and pain are all at work in torture, but so too is shame. The feverish intensity of such affect might seem distant. 'Yet shame and other affects can seem to get into our bodies, altering our understanding of our selves and our relation to the past' (Probyn 2010: 86). Writing shame literally, the shame felt in writing - brings my own writing body proximate to the torture chamber. It is along this affective line of flight that my capacity to speak finds its first deeper relation to my subject: those bodies caught up in the biopolitical imperative of the war on terror. This writing body 'becomes the battleground where ideas and experiences collide, sometimes to produce new visions of life' (2010: 89). Life - traumatized, written over, affected - that still reaches across the void towards what might otherwise be mere survival.

\section{Second movement: of writing the torturer's voice}

I began writing thinking I would tell a singular story. A young Australian caught up in events outside his control; detained by the United States and subjected to what has become known, euphemistically and detestably, as 'enhanced interrogation.' But as I wrote, this all felt too simple, too readily fitting the words that tumbled from my lips - outraged, disgusted - and not those that stuck in my throat: fascinated, attracted. Sympathy for the victim - a position without complication. What I was trying to do, I now realize, was to write torture without the twist, the tightening inward, the descent into dark places. Without the torturer.

Four encounters. The correspondence of an American military liaison officer; a man who tells Uzbeks, Egyptians and others who torture on behalf of the United States what questions to ask. [1] The moment in his memoir, Fear Up Harsh, when interrogator Tony Lagouranis (Lagouranis \& Mikaelian 2007) contemplates chopping off a detainee's fingers. Lynndie England's blank recital of what happened at Abu Ghraib in the documentary Standard Operating Procedure (Morris 2008). The scene in another documentary, Your Neighbour's Son, in which convicted torturer Michalis Petrou sits in the kitchen of his family home, his wife cooking in the background, and describes how he became one of the most notorious torturers of the Greek junta (Perdersen 1982). Each encounter brought home the intimate subjection to power of those who torture, the intensity of their experience and, perhaps above all, their sheer 
ordinariness. The victim's story, I realized, always resides somewhere between tragedy and triumph; the torturer's is often more complex.

What occurs in the torture chamber? Two bodies meet: one to be tortured, one to torture. Bodies are things of bone and sinew, but also thinking and feeling, political and social. Or, in Deleuzian terms, they are 'relations of motion and rest, speeds and slowness between particles' and the 'capacity for affecting and being affected' (Deleuze 1992: 625). In the torture chamber, I suggested earlier, affect can gain a particular intensity: it proliferates, mutates and penetrates the very particles of bodies, exciting some and forcing others into stasis. Shame, disgust, contempt, fear, pain: these are the lines of flight between one body and another; the dynamics through which tortured and torturing bodies change excite, solidify, contaminate - the very relations of motion and rest constitutive of the bodies themselves.

This change is what Deleuze and Guattari call 'becoming,' a 'verb with a consistency all its own; it does not reduce to, or lead back to, 'appearing,' 'being,' 'equalling,' or 'producing' (Deleuze \& Guattari 1987: 239). Becoming is without closure and without product; 'becoming produces nothing other than itself' (1987: 238). Becoming is about the change (continual, dynamic, unpredictable) in the composition of bodies themselves. What shape that becoming takes depends on the particularities of the encounter between bodies, on its context, location and form. There is in every body a multiplicity of possibilities of becoming. Within every body resides the potential for not only becoming-tortured but becoming-torturer. My mistake was to assume that this was not the case, that I could write an encounter in which one becoming is articulated, the other refused.

Becoming-torturer is not something that happens in a vacuum (and neither, of course, is becoming-tortured). In the war on terror the subjection of bodies to sovereign power is co-constitutive of any encounter, of any becoming. It is the biopolitical geography of the modern state that implicates each of us, that creates a plane of potential between detained bodies in Guantanamo or Abu Ghraib, US Army interrogators, and you and I. We are all complicit, all part of the same strata of knowledges, practices and power. Watch the film Standard Operating Procedure. The ease with which Harman, England and the others slid into the morass. Could that be you? Me? Someone you or I love? Becoming-torturer is not, of course, something innocent. But its potential is closer to home than we might hope.

To twist further, beyond the act and towards its aftermath, the in-between-ness that defines affect does not vanish with distance, neither in space nor time. There is a terrible after for the victim of torture, but that after is no less complex for the torturer. As Felman and Laub note in their meditation on Claude Lanzmann's film Shoah, the perpetrators of disaster are also its witnesses (1992: 207). Or, to put it differently, the uncomfortable truth is that testimony belongs not only to the victim, but to the perpetrator too. Both - in radically different yet intimately connected ways - survive. If we, the bystanders, are to be affected, if we are to know the way in which we are complicit in others becoming-torturer and becoming-tortured, both voices must be written. The voice of the torturer in the text does not elide that of the victim - it ensures it is heard in full.

\section{Third movement: of being affected by unjust ethics}


I carry a certain guilt in not allowing the victim to speak alone, that in giving the torturer voice I somehow risk legitimising the act itself. But there is also a kind of fear of the dark, of some awful descent into the writing self. Why is this so frightening? Why does part of me want to avoid the problem rather than face it? Why do people look so concerned when I tell them about my project? It cannot simply be looking at the monstrous. It must be something more, something visceral, something changeable. A fear, in the practice of writing torture, of what might be taken in. Of contagion.

Writing is an affective process. How can it not be? When I write creatively it is 'the affective response in the word choice and its resonance for the text's forms and patterns, and other words around it, that determine language use' (Freiman 2009: 5). But writing entails not only the expression of affect, but its feeling. My lip curls and nostrils flare as I write disgust, my shoulders slump inwards as I write shame. To repeat Probyn's words, 'affects can seem to get into our bodies' (2010: 86). Affect, though, is not a one-way street. It is the relational substance of encounter, operating on and between bodies. If my writing is to be what Freiman calls 'affective expression' (2009: 7) I cannot be unaffected by it. In the process of writing, my body - its relations of speed and rest, its connection to the world, its very substance - is changed. I write fragmentary instances of torture, I write its living presence within the characters of my text, and my shoulders tighten, back muscles harden into inert lumps, and my face twists into something rigid and ugly - I am glad I cannot see myself. Unwinding from this writing takes time. It is nothing like other writing, whether critical or creative. It is hard to shake, it digs in, takes over and won't readily relinquish its hold. Yet I am not simply affected by visceral discomfort - something more takes place.

And so a young man reacts to $9 / 11$ and the death of his uncle, a military man, by enlisting. He undergoes interrogation training and is deployed to Bagram Air Base, Afghanistan. The twisting slide begins. He inhabits / I write a biopolitical world; the structures of control in the cages, bodies forced into stress positions, the pressure to speak, to twist, to become. He feels / I write the shifting of values. There are no sharp falls, no sudden orders. Only a slow detachment from justice. Ethics twist in the inescapable affective dynamics of biopower. This act of writing is an encounter of bodies: bodies within the text, the body of the text, the writing body. I touch this becoming-torturer, write through and of him, and in so doing I feel the twist of the ethical slide. These ethics do not become mine, yet I cannot be unaffected by contact with them.

A kind of 'resonance' occurs (Tomkins 1963: 342). This resonance elicits sympathy, or what Gibbs describes as 'corporeal mimesis,' the 'direct body-tobody transmission of both affects and the attitudes and ideas for which affect may, under certain conditions, be a carrier' (Gibbs 2008: 135). Crucially, I am not only affected in an abstract way - not solely by some generalised Affect, but by pride, love, disgust, fear, contempt, and shame. There is something contagious here. As Gibbs writes:

Bodies can catch feelings as easily as catch fire: affect leaps from one body to another, evoking tenderness, inciting shame, igniting rage, exciting fear - in short, communicable affect can inflame nerves and muscles in a conflagration of every conceivable kind of passion. (Gibbs 2002: 1)

The contagious affect of Bagram - working through its guards and prisoners, across cages and concertina wire - works this becoming-torturer on the young American. And as it does so it catches hold of me, it leaps like fire. How is it that this man's hand can pour water on the cloth-covered face of another? How 
could mine? This is not, as Sara Ahmed suggests, a contagion in which emotions or affects become properties that are simply passed around (Ahmed 2004: 10). Rather, it is the living affective connections that form and intensify as I write. It is the way in which twisting ethical practice takes hold, not through some intellectual affinity but via affect itself. The uncertainty and violence of becoming-torturer opens up a 'zone of indeterminacy,' a site of multiple potentials, into which other bodies - this writing body - are drawn by the affective contagion of becoming (Massumi 1992: 101). The possibility of my own becoming-torturer is radically altered by this act of writing.

This is the seed of fear: the mimetic imperative of affective contagion. This mimesis is 'not a representation of the other, but a rendering' - a relation of sudden and lived similarity (Gibbs 2010: 193). Some surfacing is always possible, a turning away or untwisting from writing. I am not caged in concertina wire among the relics of Soviet machinery on the prison floor of the Facility at Bagram Air Base, nor enclosed in a military world of pressure, necessity and dehumanizing dynamics, nor required to extract words from the detained body of another. Yet affect is powerful precisely because it involves a reordering of the body: I am changed by this writing. I encounter unjust ethics in the body of another, in a body that is both affective expression and affective force. A body which, in the movement of becoming-torturer in a space subsumed by biopower, stays mimetically and affective tied to mine even as I walk away from the keyboard.

\section{Who Speaks?}

I have, so far, deliberately resisted offering any specific definition of ethics. The practice of writing torture engaged in these twisting movements is messy, complex and necessarily incomplete. It would be a mistake to search the path navigated here for a moral code. I want to follow Foucault in describing ethics as the 'conscious practice of freedom' and the 'considered form that freedom takes' (Foucault 1997: 284). The question, then, is not of the right to write, but of the necessity of writing in resisting biopower's drive to subjectify and dominate bodies. Not of whether the torturer should speak, but of the affective binding of tortured and torturer in the process of becoming-torturer. Nor, finally, of whether an unjust moral code might be convincing, but of the way in which my body, in the practice of writing torture, cannot escape affective contagion. If there is an ethics to the writing of torture, it must surely be a practice in which the dynamic of the Question itself is written against. A practice in which voices are silenced by power yet freed to speak.

\section{Notes}

1. I am most grateful to Jean Maria Arrigo of the Project for Ethics and Art in Testimony for allowing me to view her privately-held correspondence, unpublished and thus confidential, with an anonymous military intelligence liaison officer. Additional copies of selected documents are held by the Hoover Intelligence Archive and Bancroft Library. return to text

\section{Works cited}

Agamben, G 1998 Homo sacer: Sovereign power and bare life, trans D Heller-Roazen, Stanford University Press, Stanford return to text 
Agamben, G 2002 Remnants of Auschwitz: The witness and the archive, Daniel Heller-Roazen (trans), Zone Books, New York return to text

Agamben, G 2005 State of Exception, trans K Attell, University of Chicago Press, Chicago return to text

Ahmed, S 2004 The cultural politics of emotion, Routledge, New York return to text

Barthes, R 1967 'The death of the author', Aspen, 5-6

http://www.ubu.com/aspen/aspen5and6/threeEssays.html

Begg, M 2008 Enemy combatant: A British Muslim's journey to Guantanamo and back, Pocket Books, London return to text

Deleuze, G 1992 'Ethology: Spinoza and us’, in J Crary \& S Kwinter (eds) Incorporations, Zone, New York return to text

Deleuze, G \& F Guattari 1987 A thousand plateaus: Capitalism and schizophrenia, B Massumi (trans), University of Minnesota Press, Minneapolis return to text

Morris, E (dir) 2008 Standard operating procedure, Participant Productions return to text

Felman, S \& D Laub 1992 Testimony: Crises of witnessing in literature, psychoanalysis, and history, Routledge, New York return to text

Foucault, M \& P Rabinow 1997 Ethics: Subjectivity and truth, The New Press, New York return to text

Freiman, M 2009 'Keeping interest alive: Emotion and affect in creative writing', Margins and mainstreams: Refereed conference papers of the 14th Annual AAWP Conference, http://www.aawp.org.au/files/Freiman.pdf (Access date: 16 September 2011) return to text

Gibbs, A 2002 'Contagious feelings: Pauline Hanson and the epidemiology of affect', Australian humanities review 25 (Mar/May):

http://www.australianhumanitiesreview.org/archive/Issue-December-2001/gibbs.html return to text

Gibbs, A 2008 'Panic! affect contagion, mimesis and suggestion in the social field', Cultural studies review, 14, 2: 16 return to text

Gibbs, A 2010 ‘After affect: Sympathy, synchrony and mimetic communication’, in M Gregg \& GJ Seigworth (eds) The affect theory reader, Duke University Press, Durham, NC: 186-205 return to text

Hicks, D 2010 Guantanamo: My Journey, William Heinemann, Sydney return to text

Kurnaz, M 2008 Five years of my life: An innocent man in Guantanamo, Palgrave Macmillan, New York return to text

Lagouranis, T \& A Mikaelian 2007 Fear up harsh: An army interrogator's dark journey through Iraq, New American Library, New York return to text

Massumi, B 1992 A user's guide to capitalism and schizophrenia: Deviations from Deleuze and Guattari, MIT Press, Cambridge, MA return to text

Perdersen, JF (dir) 1982 Your Neighbour's Son, Ebbe Preisler Film/TV aps return to text

Probyn, E 2010 'Writing shame', in M Gregg \& GJ Seigworth (eds) The affect theory reader, Duke University Press, Durham, NC: 71-90 return to text

Rejali, D 2007 Torture and democracy, Princeton University Press, Princeton return to text

Scarry, E 1985 The body in pain: the making and unmaking of the world, Oxford University Press, New York return to text

Tomkins, SS 1963 Affect, imagery, consciousness Vol 2: The negative affects, Springer / Tavistock, New York, London return to text 
Michael Richardson is completing a Doctorate of Creative Arts with the Writing \& Society Research Centre at the University of Western Sydney. His research into narrative, bodies and torture during the war on terror is comprised of both a novel and an academic thesis. He was previously the only Australian speech writer in Canadian politics. An earlier version of this paper was presented at the 2011 AAWP Conference and was awarded the Co-op Bookshop Postgraduate Prize.

\section{TEXT}

Vol 16 No 1 April 2012

http://www.textjournal.com.au

Editors: Nigel Krauth \& Enza Gandolfo

Text@griffith.edu.au 